\title{
Practices of Instructional Supervision in Secondary Schools of Bale Zone of Oromia Region
}

\author{
Fekedu Dechasa Heyi* \\ College of Education and Behavioral Studies, Department of Educational planning and Management, Madda \\ Walabu University, Ethiopia \\ Ayele Kumsa Hordofa \\ College of Education and Behavioral Studies, Department of Adult Educations and Community Development, \\ Madda Walabu University
}

\begin{abstract}
School-based instructional supervision is focusing mainly on the total school improvement and quality of education provided for the learner. Therefore, the main purpose of the study was to investigate the practices of instructional supervision in secondary schools of Bale Zone. Descriptive survey design was employed to gather from nine randomly selected secondary schools in Bale Zone. Out of the total population of respondents, $182(52.8 \%)$ teachers were selected using systematic random sampling technique. In addition out of 81 instructional supervision committee members, 54(66.7\%) were included in the study by simple random sampling techniques. Nine principals and, eight secondary school supervisors were participated by purposive sampling. Questionnaire and interview were employed as instrument of data collection. Frequency, percentage, and chi-square analysis were employed to analyze quantitative data. Qualitative data was thematically categorized and narrated for the purpose of triangulation. The results of the study revealed that the practices of instructional supervision approaches and their contribution to teachers' professional development were low. Instructional supervisors were found to get involved in the difficult task of supervision without having prior trainings, and their contributions were also unsatisfactory. There were also lack of trained supervisors, manuals, training, shortage of budget, and high teaching load of supervisors hinder proper implementation of instructional supervision. As a result, awareness creation should be given to instructional supervisors and teachers through seminars, workshops and discussion forums in order to bring professional growth of teachers and improving their instructional practices. Moreover, suggestions should be forwarded by concerned bodies so as to solve the factors that hinder proper implementation of instructional supervision practices.
\end{abstract}

Keywords: Continuous professional development, Instructional Supervision, Principal, secondary school teachers DOI: $10.7176 / \mathrm{JEP} / 11-7-01$

Publication date:March $31^{\text {st }} 2020$

Schools are the formal agencies of education where the future citizens are shaped and developed through the process of teaching and learning. So schools need to help all students to develop their potentials to the highest level. This requires the effectiveness and commitment of the stakeholders particularly teachers, school leaders and management (Aggarwal, 1985). So schools have to improve their basic functions of teaching and learning process that aims at helping and empowering all students to raise their broad outcomes through instructional improvement. To achieve these expected outcomes, education system must ensure the existence of relevant curriculum; and improved instructional situations and professionally motivated and competent teachers. In line with this, Mohanty (1990) stated that in educational system, there are different variables that have their own contribution for its development. Of all, the one which is the main input and important is the teacher who needs effective instructional support. Teacher's professional competence and efforts of students', instructional supervision and classroom teaching-learning situation can affect quality of education (MoE, 2002). Ahmed (1998) also mentioned that, the effectiveness and efficiency of an organization are relied on the quality of performance of the staff. Schools are within the dynamic and changing social system, teachers and other staff personnel continually face new and challenging situation every time. Thus teachers have great need to get appropriate supervisory support to become professionally competent.

Effective learning of students is promoted through the provision of effective supervisory support to teachers. In this regards, Chanyalew (2005) stated that instructional supervision approaches are important in promoting teachers professional development as they are frequently designed to identify and exemplify various effective classroom techniques and teacher skill to promote better teaching and learning. Similarly, Supervision Manual of MoE (1987) illustrated the role of supervision in school system as ensuring curriculum implementation, providing direct technical support to teachers, providing on job training to teachers, conducting formative education program evaluation, monitoring and evaluation. School-based instructional supervision is focusing mainly on the total school improvement and quality of education provided for the learner. Supporting this, MoE (1995) mentioned that the main focus of supervision became providing support for teachers and enhances their role as key 
professional decision makers in practice of teaching.

It is believed that the improvement of schools would not be accomplished without improving teachers' education. The quality of teachers' education is determined by the provision of adequate supervision support from supervisors. The realization of professional competence of teachers and the quality of education remains questionable unless due emphasis is given from education officials at different levels to implement instructional supervision effectively. Therefore, the concern of this study is to see the current practice of instructional supervision approaches and factors affect this practice.

Over a long period of time supervision had been based on hierarchical principles. The role of the teacher was to impart basic truths to children, whereas the role of the supervisor was to serve as the "inspector" to ensure the curriculum had been followed and essential skills were learned (Ebmeier and Nicklaus, 1999). As this orientation toward teacher supervision became more common, many teachers were afraid to ask supervisors for help or to seek collegial assistance for fear that doing so would expose weaknesses in their teaching, which could be reflected later in low evaluations and possible punitive actions. As Ebmeier and Nicklaus (1999) noted, supervision as an evaluation tool reduced the possibility of nurturing collegiality, collaboration, and reflective practice.

In the current practice, instructional supervision approaches supposed to focus mainly on teachers' professional growth so as to enhance instructional practice of schools and to bring about the desired change of behavior on the parts of their students.

However, from experience of the researcher, the existing reality of supervision in the secondary schools of Bale Zone does not seem to suggest a positive impact of supervision approaches on instructional improvement. It is heard from some secondary school teachers that they do not receive what they except from supervisors, supervisors often not seen in schools. Being remote figures without realistic connections with the reality of the classroom, they usually engage in routine inspection of administrative nature. As Chanyalew (2005) illustrated, many teachers have been heard complaining that conferences and workshops at grassroots level are nonexistent. Moreover, teachers are not benefiting from supervisors. Thus, teachers face difficulties not only in tackling instructional problems but also in implementation of curriculum and new instructional approaches.

As far as the practice of instructional supervision in primary and secondary schools is concerned, some researches were conducted a research in different regions. For instance Haile (2006) conducted a study on supervisors' techniques, Chanyalew (2005) on supervisory procedures, and Atiklt (2008) on major functions of supervision. Their studies did not address the practice and contribution of instructional supervision approaches for promoting teachers' professional development.

Besides, to the knowledge of the researchers, there is no study which addressed the practice and contributions of instructional supervision approaches for promoting teachers' professional development in Bale Zone. Due to this, the researchers decided to fill the gap by conducting research in Bale Zone. Therefore, the main reasons and purpose of the study are to assess the contribution, the current practice, the instructional supervision approach preferred by teachers and to examine factors hindering instructional supervision approaches for teachers' professional development in secondary schools of Bale Zone. The result of the study also have its own contributions for those who need in depth on the area.

To these end, the following basic questions were raised to answer in the course of the study.

1. To what extent do instructional supervision being practiced by supervisors for teachers' professional development in secondary schools of Bale Zone?

2. What are the major factors hindering the practice of instructional supervision in secondary schools of Bale Zone?

3. What are the possible solutions to be forwarded to enhance instructional supervision in secondary schools of Bale Zone?

The general objective of this study was to assess the practice of school based instructional supervision teachers' professional development and factors hindering the practice of instructional supervision and secondary school teachers' professional development.

\section{Materials and Methods}

The aim of the study was to investigate the practices of instructional supervision in secondary schools of Bale Zone. Based on its aim, descriptive survey design was employed. Because it can provide precise and deep information concerning the current practice of instructional supervision approaches in the study area. Besides, qualitative research methodology has been employed to supplement the study with the information that was collected using semi structured interview.

\section{Sources of Data}

Teachers, instructional supervision committee members (vice-principals, senior-teachers, department-heads, and unit-leaders), school principals and secondary school supervisors of Bale zone were used as primary sources of data 


\section{Sample and Sampling Techniques}

Out of 36 government secondary schools, in Bale Zone, 9 (25\%)Sanbitu, Robe Galama, Goba Finca Bamo, Dinsho, Ali, Mena, Ginir twon, Selka, Maliyu)secondary schools were selected, using simple random sampling technique. With regards to participants, there are 340 teachers in 9 sample high schools. By Krejcie and Morgan (1970) population size formula, the determining sample size for 345 should be approximately 182 . Accordingly, out of 345 teachers who found in 9 sample schools, $182(52.8 \%)$ were selected by using systematic random sampling technique. All 54 instructional supervision committee members (vice- principals, department-heads, seniorteachers and unit-leaders) of sample schools were included by available sampling, because all are important for the study. Finally, 9 sampled school principals and 8 secondary school supervisors were included in the study by purposive sampling techniques as follows.

Table 1: Total population and sample size of each sample school teachers

\begin{tabular}{|c|c|c|c|c|c|}
\hline No & School name & Total population & Sample size & Percent & Sample technique \\
\hline 1 & Robe Galema & 45 & 24 & $52.8 \%$ & $\begin{array}{ll}\text { Systematic } & \text { random } \\
\text { sampling } & \\
\end{array}$ \\
\hline 2 & Obera & 23 & 12 & $52.8 \%$ & "” \\
\hline 3 & Goba & 73 & 39 & $52.8 \%$ & “" \\
\hline 4 & Dinsho & 14 & 7 & $52.8 \%$ & "» \\
\hline 5 & Agarfa & 51 & 27 & $52.8 \%$ & "» \\
\hline 6 & Mena & 29 & 15 & $52.8 \%$ & “" \\
\hline 7 & Giniir & 63 & 33 & $52.8 \%$ & "” \\
\hline 8 & Selka & 11 & 6 & $52.8 \%$ & "” \\
\hline 9 & Goro & 36 & 19 & $52.8 \%$ & "” \\
\hline \multicolumn{2}{|c|}{ Sub total } & 345 & 182 & $52.8 \%$ & “" \\
\hline & Respondents & Total population & Sample size & $\%$ & Sampling technique \\
\hline \multicolumn{6}{|r|}{ samping tectimique } \\
\hline 2 & Principals & 9 & 9 & $100 \%$ & Purposive \\
\hline 3 & $\begin{array}{l}\text { instructional } \\
\text { supervisors }\end{array}$ & 54 & 54 & $100 \%$ & Purposive \\
\hline 4 & $\begin{array}{l}\text { High school } \\
\text { supervisors }\end{array}$ & 8 & 8 & $100 \%$ & purposive \\
\hline$G$ & otal & 416 & 253 & $60.8 \%$ & \\
\hline
\end{tabular}

Source Bale Zone Education Office 2012 statistic

\section{Data Collection Instruments}

\section{Questionnaire}

Closed and open-ended types of questionnaires were set for teachers and instructional supervision committee members, in light of the literature reviewed. All of the questionnaires were prepared in English, as the researchers believe that the respondents can understand the items.

Before data collection, validity and reliability test were done necessarily. After the pilot test some of the items were improved and a few items were removed. Besides, the reliability of the items was tested using Cronbach Alpha method and the result displayed ( $\mathrm{r}=0.81$ ) which is reliable. According to the standard set, Cronbach Alpha value greater than 0.5 is taken as adequate for social science research purpose (Montee, 1990).

\section{Interview}

Interviews were administered to the principals, and high school supervisors at the woreda level. Because, they are small in number and their position is important in describing the practice of instructional supervision in their school. According to Best and Kahn (2003), interview makes possible what a person knows (knowledge), what a person likes (values and performance) and what a person think (attitude and opinion) by providing access to what is inside a person's mind.

\section{Methods of Data Analysis}

Data collected through close ended questionnaires, were tallied and tabulated. The interpretations have been made with the help of frequency, percentage and mean. In addition, chi-square test has been applied to interpret closeended questions, so as to test whether there is any significant difference between the response of teachers and instructional supervisors.

On the other hand, for better analysis, the 5 rank responses of the questionnaires were made to categorize into three scales (agree, undecided, disagree). Finally, the data collected through interview and open-ended questionnaires has been presented, analyzed, narrated, and organized in systematical form, by supplementing the data gathered through close ended questionnaires. In addition to this, the researcher used qualitative thematic 
written techniques and give attention to quotations from the respondents.

Result and Discussion

Table 2. Efforts of instructional supervisors in promoting teachers TPD

\begin{tabular}{|c|c|c|c|c|c|c|c|c|c|c|c|}
\hline \multirow[t]{3}{*}{ No } & \multirow[t]{3}{*}{ Items } & \multirow{3}{*}{$\begin{array}{c}\text { Respon } \\
\text { dents }\end{array}$} & \multicolumn{8}{|c|}{ Responses } & \multirow{3}{*}{$\begin{array}{l}\text { Computed } \\
\chi^{2}\end{array}$} \\
\hline & & & \multicolumn{2}{|c|}{ Disagree } & \multicolumn{2}{|c|}{ Undecided } & \multicolumn{2}{|c|}{ Agree } & \multicolumn{2}{|c|}{ Total } & \\
\hline & & & No & $\%$ & No & $\%$ & No & $\%$ & No & $\%$ & \\
\hline \multirow[t]{4}{*}{1} & Supervisors organize and & Teacher & 66 & 36.3 & 21 & 11.5 & 95 & 52.2 & 182 & 100 & \multirow[t]{4}{*}{0.896} \\
\hline & support induction & Supervis & 19 & 35.2 & 4 & 7.4 & 31 & 57.4 & 54 & 100 & \\
\hline & programs for beginner or & ion & & & & & & & & & \\
\hline & $\begin{array}{l}\text { new teachers in the } \\
\text { school. }\end{array}$ & Total & 85 & 36.0 & 25 & 10.6 & 126 & 53.4 & 236 & 100 & \\
\hline \multirow[t]{3}{*}{2} & Supervisors facilitate & Teacher & 93 & 51.1 & 11 & 6.0 & 78 & 42.9 & 182 & 100 & \multirow[t]{3}{*}{1.029} \\
\hline & $\begin{array}{l}\text { professional } \\
\text { development of teachers }\end{array}$ & $\begin{array}{l}\text { Supervis } \\
\text { ion }\end{array}$ & 29 & 53.7 & 5 & 9.3 & 20 & 37.0 & 54 & 100 & \\
\hline & $\begin{array}{l}\text { through mentoring } \\
\text { programs. }\end{array}$ & Total & 122 & 51.7 & 16 & 6.8 & 98 & 41.5 & 236 & 100 & \\
\hline \multirow[t]{3}{*}{3} & Supervisors organize & Teacher & 107 & 58.8 & 14 & 7.7 & 61 & 33.5 & 182 & 100 & \multirow[t]{3}{*}{0.769} \\
\hline & $\begin{array}{l}\text { collegial or pear } \\
\text { coaching techniques of }\end{array}$ & $\begin{array}{l}\text { Supervis } \\
\text { ion }\end{array}$ & 32 & 59.3 & 6 & 11.1 & 16 & 29.6 & 54 & 100 & \\
\hline & $\begin{array}{l}\text { supervision for teachers } \\
\text { professional growth }\end{array}$ & Total & 139 & 58.9 & 20 & 8.5 & 77 & 32.6 & 236 & 100 & \\
\hline \multirow[t]{3}{*}{4} & Supervisors assist & Teacher & 84 & 46.2 & 28 & 15.4 & 70 & 38.5 & 182 & 100 & \multirow[t]{3}{*}{1.430} \\
\hline & $\begin{array}{l}\text { teachers to undertake } \\
\text { joint planning of }\end{array}$ & $\begin{array}{l}\text { Supervis } \\
\text { ion }\end{array}$ & 28 & 51.9 & 10 & 18.5 & 16 & 29.6 & 54 & 100 & \\
\hline & $\begin{array}{l}\text { experience sharing } \\
\text { programs in school } \\
\text { context }\end{array}$ & Total & 112 & 47.5 & 38 & 16.1 & 86 & 36.4 & 236 & 100 & \\
\hline \multirow[t]{3}{*}{5} & Supervisors facilitate & Teacher & 114 & 62.6 & 14 & 7.7 & 54 & 29.7 & 182 & 100 & \multirow[t]{3}{*}{0.651} \\
\hline & $\begin{array}{l}\text { professional } \\
\text { development of teachers }\end{array}$ & $\begin{array}{l}\text { Supervis } \\
\text { ion }\end{array}$ & 32 & 59.3 & 6 & 11.1 & 16 & 29.6 & 54 & 100 & \\
\hline & $\begin{array}{l}\text { through short term } \\
\text { training, workshops, } \\
\text { seminars etc. }\end{array}$ & Total & 146 & 61.9 & 20 & 8.5 & 70 & 29.7 & 236 & 100 & \\
\hline
\end{tabular}

The table value $\chi^{2}=5.991$ at 0.05 significant levels with two degrees of freedom

As indicated in table 2, item 1, the majorities 95 (52.2\%) of teacher and 31 (57.4\%) of supervisor respondents confirmed that induction program have been taken place in their school. on the other hand, $66(36.3 \%)$ of teachers, $19(35.2 \%)$ of supervisor did not implement induction program for newly employed teachers. The computed chisquare value $\mathrm{x}^{2}=0.896$ was less than the table value of $\chi^{2}=5.991$, for $\mathrm{df}=2$, at 0.05 level of significance, which implies there is no statistically significant difference between the respondents responses. In the interview with the school principals and secondary school supervisors, all the interviewees claimed that teachers had chance of getting induction or mentoring service while they were beginner or new to the schools they were assign to teach. This might depict us that due to the new CPD program started in the year 2007, the beginner teacher had a chance of having an induction or mentoring program in schools of the region. In support of this, McBirdge (1996:15) argued that Mentoring or induction is aimed at helping new requited teachers to develop self confidence and to avoiding unnecessary tension and future malfunction.

In item 2, 93 (51.1\%) teachers and 29 (53.7\%) supervisors' respondents showed their disagreement on supervisors mentoring program. This implied that the practice were ineffective. On the other hand, from the interview held with the principals, vice principals and secondary school supervisors, instructional supervisors were not using different mechanisms to enhance professional competence of teachers by providing the latest information. Hence, it is possible to conclude that the role of supervisors to enhance professional competence of teachers is not almost implemented sufficiently.

In light of this idea, Hewto (1988 cited in Moon et al., 2006:151) asserted that school based professional development as planned process which enhances the quality of pupil learning by identifying, clarifying and meeting the individual needs of staff with in a context of the institution as a whole. It can be achieved through variety of means such as conferences, workshops, seminars, meetings, study groups, research and projects, visitation to other schools and classrooms. When a teaching staff competent through the practices the overall objective will be achieved. 
According to item 3,139(58.9\%) respondents were disagreed on supervisors organizing collegial or peer coaching techniques of supervision for teachers' professional development. $84(46.2 \%)$ teachers and 28 (51.9\%) supervisors of item 4 of undertake joint planning of experience sharing programs, they disagreed on the practices. In this respect the practices were low.

In the last item of table 2, respondents were requested whether supervisory support endeavor to create awareness of engaging in professional learning or not. Accordingly, the majority 114 (62.6\%) of teachers and 32 $(59.3 \%)$ of supervisors contended their disagreement that implied, practices in this respect were ineffective.

The responses were also exposed to chi-square tests to see if there was difference in response on the issue. Hence, the chi-square revealed that the table value was greater than the computed values for item 6 to 9 at significant level of 0.05 with two degree of freedom, which implies no significance difference with the view of two groups of respondent.

Most of the interview participants agreed, a few number of training might not allowed them to judge enough whether school level trainings organized by instructional supervisors enable teacher to bring the expected outcome in professional competence of teachers.

Supporting this, as noted in the literature, Lue (2004) argued that in service training at school level is one of the means to achieve professional development of teachers' of the school. Through the training, teachers could improve teaching methodologies and curriculum innovations, develop mutual support and stand for common goals. Similarly, Moon et al. (2006) described, school based staff development as a planned process of development which enhances the quality of pupil learning by identifying, clarifying and meeting the individual needs of staff with in a context of the instruction as a whole. But this is not practiced in secondary school of Bale zone

\section{The frequency of instructional supervision conducted in school}

Table 3. Respondents view on frequency of instructional supervision conducted in their school

\begin{tabular}{|c|c|c|c|c|c|c|c|c|c|c|c|c|c|c|}
\hline \multirow[t]{3}{*}{ Items } & \multirow{3}{*}{$\begin{array}{c}\text { Responde } \\
\text { nts }\end{array}$} & \multicolumn{12}{|c|}{ Responses } & \multirow{3}{*}{$\begin{array}{l}\text { Computed } \\
\chi^{2}\end{array}$} \\
\hline & & \multicolumn{2}{|c|}{ Never } & \multicolumn{2}{|c|}{$\begin{array}{c}\text { Once a } \\
\text { year }\end{array}$} & \multicolumn{2}{|c|}{$\begin{array}{c}\text { Once a } \\
\text { semester }\end{array}$} & \multicolumn{2}{|c|}{ Monthly } & \multicolumn{2}{|c|}{ Weekly } & \multicolumn{2}{|c|}{ Total } & \\
\hline & & No & $\%$ & No & $\%$ & No & $\%$ & No & $\%$ & No & $\%$ & No & $\%$ & \\
\hline \multirow{3}{*}{$\begin{array}{l}\text { How } \\
\text { frequently } \\
\text { instructional } \\
\text { supervision } \\
\text { conducted in } \\
\text { your school? }\end{array}$} & Teacher & 44 & 24.2 & 33 & 18.1 & 96 & 52.8 & 5 & 2.8 & 4 & 1.8 & 182 & 100 & \multirow[t]{3}{*}{1.862} \\
\hline & Supervisor & 16 & 29.6 & 9 & 16.7 & 28 & 51.9 & 1 & 1.9 & - & - & 54 & 100 & \\
\hline & Total & 60 & 25.4 & 42 & 17.8 & 124 & 52.5 & 6 & 2.6 & 4 & 1.7 & 236 & 100 & \\
\hline
\end{tabular}

The table value $\chi^{2}=9.488$ at 0.05 significant levels with four degrees of freedom

As indicated in table 3, majority $96(52.8 \%)$ of teachers and $28(51.9 \%)$ supervisors were responded that instructional supervision was conducted once a semester. The chi-square revealed that the table value $\chi^{2}=9.488$ was extremely greater than the computed values $\chi^{2}=1.862$ at significant level of 0.05 with four degrees of freedom, which implies no significant difference with the view of two groups of respondents.

According to the interviewees, instructional supervision was conducted once a semester for the purpose of teacher's performance appraisal. Further, supervisors have more than 20 work load and they have no time to conduct supervision, according to the manual of regional education bureau weekly supervisors have 10 teaching load (OREB, 2007). 
Table 4. Respondents views on contribution of instructional supervision approaches

\begin{tabular}{|c|c|c|c|c|c|c|c|c|c|c|c|}
\hline \multirow[t]{3}{*}{ No } & \multirow[t]{3}{*}{ Items } & \multirow[t]{3}{*}{ Respondents } & \multicolumn{8}{|c|}{ Responses } & \multirow{3}{*}{$\begin{array}{l}\text { Computed } \\
\chi^{2}\end{array}$} \\
\hline & & & \multicolumn{2}{|c|}{ Disagree } & \multicolumn{2}{|c|}{ Undecided } & \multicolumn{2}{|c|}{ Agree } & \multicolumn{2}{|c|}{ Total } & \\
\hline & & & No & $\%$ & No & $\%$ & № & $\%$ & No & $\%$ & \\
\hline \multirow[t]{3}{*}{1} & \multirow{3}{*}{$\begin{array}{l}\text { Instructional } \\
\text { supervision helps } \\
\text { teachers to arrange } \\
\text { conducive situation } \\
\text { to instructional } \\
\text { improvement }\end{array}$} & Teacher & 107 & 58.8 & 7 & 3.8 & 68 & 37.4 & 182 & 100 & 10.941 \\
\hline & & Supervision & 18 & 33.3 & 4 & 7.4 & 32 & 59.3 & 54 & 100 & \\
\hline & & Total & 125 & 53.0 & 11 & 4.7 & 100 & 42.4 & 236 & 100 & \\
\hline \multirow[t]{3}{*}{2} & \multirow{3}{*}{$\begin{array}{l}\text { Instructional } \\
\text { supervision practice } \\
\text { helps teachers to } \\
\text { create cooperative } \\
\text { spirit with in school } \\
\text { community }\end{array}$} & Teacher & 103 & 56.6 & 12 & 6.6 & 67 & 36.8 & 182 & 100 & 0.910 \\
\hline & & Supervision & 27 & 50 & 5 & 9.3 & 22 & 40.7 & 54 & 100 & \\
\hline & & Total & 130 & 55.1 & 17 & 7.2 & 89 & 37.7 & 236 & 100 & \\
\hline \multirow[t]{3}{*}{3} & \multirow{3}{*}{$\begin{array}{l}\text { Instructional } \\
\text { supervision } \\
\text { enhances and } \\
\text { improves } \\
\text { instructional } \\
\text { effectiveness in } \\
\text { promoting student } \\
\text { learning }\end{array}$} & Teacher & 91 & 50.0 & 21 & 11.5 & 70 & 38.5 & 182 & 100 & 4.715 \\
\hline & & Supervision & 18 & 33.3 & 9 & 16.7 & 27 & 50.0 & 54 & 100 & \\
\hline & & Total & 109 & 46.2 & 30 & 12.7 & 97 & 41.1 & 236 & 100 & \\
\hline \multirow[t]{3}{*}{4} & \multirow{3}{*}{$\begin{array}{l}\text { Instructional } \\
\text { supervision assists } \\
\text { teachers in the } \\
\text { preparation and } \\
\text { provision } \\
\text { supportive } \\
\text { manuals }\end{array}$} & Teacher & 101 & 55.5 & 16 & 8.8 & 65 & 35.7 & 182 & 100 & 0.055 \\
\hline & & Supervision & 29 & 53.7 & 5 & 9.3 & 20 & 37.0 & 54 & 100 & \\
\hline & & Total & 130 & 55.1 & 21 & 8.9 & 85 & 36.0 & 236 & 100 & \\
\hline
\end{tabular}

The table value $\chi^{2}=5.991$ at 0.05 significant levels with two degrees of freedom

Regarding the effort of supervision to arrange and promoting situation conducive to instructional improvement 107 (58.8\%) teacher witnessed that they never hold the practice. Whereas, 32 (59.3\%) of supervisor respondents pointed out that the non existence of the practice. A chi-square test value of $\chi^{2}=5.991$ was found to be less than the calculated $\chi^{2}=10.941$, for $\mathrm{df}=2$, at 0.05 level of significant, which implies there is statistically significant difference among the respondents response regarding item 1 of table 3 .

Principals and secondary school supervisors interviewees confirmed that, instructional supervisors were not arranging and promoting situation conducive to instructional improvement because of lack of time, lack of knowledge and skills of how, to arrange conducive working atmosphere to instructional improvement.

On item 2 of table above, $103(56.6 \%)$ teachers and $27(50.0 \%)$ supervisors were disagreed to the idea of instructional supervision help teachers to create cooperative spirit within school community. The computed chisquare indicated no significant difference between the views of two groups.

In line with this, OREB (2007:14) in its guideline for educational supervision works for schools pointed out teachers have to be encouraged by supervisors of their own school to share their experiences of good methodology, classroom organization, lesson plan and media preparation and personal life.

Item 3 of Table 4 deals with the extent of supervisory practice of school base supervisors help teacher to enhance and to improve instructional effectiveness in promoting student learning. To this end, 91(50.0\%) teacher respondents disagreed that supervisors did not perform the activity. On the contrary, $27(50.0 \%)$ supervisor respondents agreed that the activity is accomplished. computed chi-square value $\mathrm{x}^{2}=0.992 \mathrm{x}^{2}=0.045$, and $\mathrm{x}^{2}=4.715$ less than the table value $\mathrm{x}^{2}=5.991$ at 0.05 significant level with two degree of freedom. This means that there is no a significant difference between the response of two group respondents.

The data obtained from the interview revealed that, the tasks and duties performed by instructional supervisors were ineffective and failed to help teachers to be efficient in their instructional activities.

In item 4 of Table 4 , teaches and supervisor respondents asked whether supervisory practice of school based supervisors assists teachers in evaluating the existing curriculum materials or not. Accordingly, the majoritiy 112 
$(61.5 \%)$ of teachers and $33(61.1 \%)$ of supervisors were not agreed.

On the same table, $101(55.5 \%)$ of teachers and 29 (53.7\%) of supervisors respondents were disagreed to the idea of Instructional supervision assists teachers in the preparation and provision of supportive teaching manuals and materials. This revealed that practices in this respect were in effective.

The computed chi-square value of item 4 are less than the table value $\chi^{2}=5.991$ at 0.05 significant levels with two degree of freedom. This revealed that there is no significance difference among the response of the two groups of respondents.

As confirmed the interview held with principals and woreda secondary school supervisors, instructional supervisors' effort enabling teachers to evaluate the curriculum materials; and to prepare supporting teaching manuals and materials found to be ineffective.

Supporting this Dull (1981) indicated, supervisors working activities include, helping teachers to prepare instructional materials not otherwise available. In line with the above analysis, OREB (2007:15-16) reported that one of the responsibilities and duties of instructional supervision committee is evaluating and controlling the implementing of curriculum and standards of the whole education system.

Depending on the above finding the researcher concluded that, instructional supervision in secondary schools of Bale zone have not contributed much for teachers' professional development.

Views on major factors affecting instructional supervision practice

As has been presented in tables 1 up to 3 below respondents were asked to rate their agreement on the expected major factors that could possibly affect instructional supervision in the secondary schools.

Teachers perception towards supervision

Table 5. Respondents views on teachers' perception of supervision

\begin{tabular}{|c|c|c|c|c|c|c|c|c|c|c|c|}
\hline \multirow[t]{3}{*}{ No } & \multirow[t]{3}{*}{ Items } & \multirow{3}{*}{$\begin{array}{c}\text { Respondent } \\
\text { s }\end{array}$} & \multicolumn{8}{|c|}{ Responses } & \multirow{3}{*}{$\begin{array}{l}\text { Com } \\
\text { puted } \\
\chi^{2}\end{array}$} \\
\hline & & & \multicolumn{2}{|c|}{ Disagree } & \multicolumn{2}{|c|}{ Undecided } & \multicolumn{2}{|c|}{ Agree } & \multicolumn{2}{|c|}{ Total } & \\
\hline & & & No & $\%$ & № & $\%$ & No & $\%$ & No & $\%$ & \\
\hline \multirow[t]{3}{*}{1} & Teachers & Teacher & 61 & 33.5 & 23 & 12.6 & 98 & 53.9 & 182 & 100 & 4.686 \\
\hline & perceive & Supervision & 12 & 22.2 & 4 & 7.4 & 38 & 70.4 & 54 & 100 & \\
\hline & $\begin{array}{l}\text { supervision as a } \\
\text { fault finding than } \\
\text { helping activity. }\end{array}$ & Total & 73 & 30.9 & 27 & 11.5 & 136 & 59.6 & 236 & 100 & \\
\hline \multirow[t]{3}{*}{2} & Teachers & Teacher & 102 & 56.1 & 9 & 4.9 & 71 & 39.0 & 182 & 100 & 6.120 \\
\hline & perceive & Supervision & 28 & 51.9 & 8 & 14.8 & 18 & 33.3 & 54 & 100 & \\
\hline & $\begin{array}{l}\text { supervision as a } \\
\text { means to improve } \\
\text { instruction. }\end{array}$ & Total & 130 & 55.1 & 17 & 7.2 & 89 & 37.7 & 236 & 100 & \\
\hline \multirow[t]{3}{*}{3} & Teachers & Teacher & 70 & 38.5 & 14 & 7.7 & 98 & 53.8 & 182 & 100 & 3.919 \\
\hline & perceive & Supervision & 20 & 37.0 & 9 & 16.7 & 25 & 46.3 & 54 & 100 & \\
\hline & $\begin{array}{ll}\text { supervisors } & \text { as } \\
\text { incompetent } & \text { to }\end{array}$ & Total & 90 & 38.1 & 23 & 9.8 & 123 & 52.1 & 236 & 100 & \\
\hline
\end{tabular}

The table value $\chi^{2}=5.991$ at 0.05 significant levels with four degrees of freedom

As shown in table 5 of item 1 , teacher and supervisor respondent asked whether or not teachers perceive supervision as a fault finding rather than helping activity. Accordingly, 98 (53.9\%) teachers, and 38 (70.4\%) supervisors respondents agreed on the existence of such perception.

In the same table of item 2, majority $102(56.1 \%)$ teacher and 28 (51.9\%) supervisor respondents disagreed on teachers perception is positive to a supervision as a means to improve instruction. The computed chi- square value for item $2, \chi^{2}=6.120$ is greater than the table value $\chi^{2}=5.991$ at a significant level of 0.05 with two degree of freedom. Hence, there is significant difference in response of the two groups

As can be observed in table 5 item 3, the respondents were asked whether or not teachers perceive supervisors as in competent to the position. In light of these, majority $98(53.9 \%)$ teachers and $25(46.3 \%)$ supervisors respondents were agreed on the supervisors' incompetence to the position.

A chi-square test was calculated to check whether the opinion difference exists among the two groups of respondents. Accordingly, the computed chi-square values of item 1 and 3 in the above table are less than the table value $\chi^{2}=5.991$ at 0.05 significant levels with two degrees of freedom. This implies that there is no significant difference between the responses of the two groups of respondents.

In light of the forgoing analysis, Jhonson and Johnson (2002) teachers have a trust their supervisors to develop positive views towards school based supervision and instruction. When teachers cannot trust their supervisors their 
ability to deliver quality instruction is seriously impaired. Thus, teachers' perception of supervision is valuable to improve instruction.

Training related factors that hinder instructional supervision

Table 6. Respondents' views on training related factors

\begin{tabular}{|c|c|c|c|c|c|c|c|c|c|c|c|}
\hline \multirow[t]{3}{*}{ No } & \multirow[t]{3}{*}{ Items } & \multirow[t]{3}{*}{ Respondents } & \multicolumn{8}{|c|}{ Responses } & \multirow{3}{*}{$\begin{array}{l}\text { Computed } \\
\chi^{2}\end{array}$} \\
\hline & & & \multicolumn{2}{|c|}{ Disagree } & \multicolumn{2}{|c|}{ Undecided } & \multicolumn{2}{|c|}{ Agree } & \multicolumn{2}{|c|}{ Total } & \\
\hline & & & No & $\%$ & No & $\%$ & No & $\%$ & No & $\%$ & \\
\hline \multirow[t]{3}{*}{1} & "Supervisors are well & Teacher & 98 & $\begin{array}{c}53.8 \\
\end{array}$ & 18 & 9.9 & 66 & 36.3 & 182 & 100 & 1.331 \\
\hline & trained in & Supervisor & 33 & 61.1 & 6 & 11.1 & 15 & 27.8 & 54 & 100 & \\
\hline & $\begin{array}{l}\text { instructional } \\
\text { supervision to give } \\
\text { support to teachers }\end{array}$ & Total & 131 & 55.5 & 24 & 10.2 & 81 & 34.3 & 236 & 100 & \\
\hline \multirow[t]{3}{*}{2} & Workshops, & Teacher & 112 & 61.5 & 19 & 10.4 & 51 & 28.0 & 182 & 100 & 2.327 \\
\hline & seminars, trainings & Supervisor & 36 & 66.7 & 8 & 14.8 & 10 & 18.5 & 54 & 100 & \\
\hline & $\begin{array}{lr}\text { were arranged for } \\
\text { supervisors } & \text { to } \\
\text { upgrade } & \text { their } \\
\text { advisory status. } & \end{array}$ & Total & 148 & 62.7 & 27 & 11.4 & 61 & 25.9 & 236 & 100 & \\
\hline \multirow[t]{3}{*}{3} & Experience sharing & Teacher & 91 & 50.0 & 18 & 9.9 & 73 & 40.1 & 182 & 100 & 5.938 \\
\hline & session has been & Supervisor & 34 & 63.0 & 8 & 14.8 & 12 & 22.2 & 54 & 100 & \\
\hline & $\begin{array}{ll}\text { organized } & \text { for } \\
\text { instructional } & \\
\text { supervisors. } & \end{array}$ & Total & 125 & 53.0 & 26 & 11.0 & 85 & 36.0 & 236 & 100 & \\
\hline
\end{tabular}

The table value $\mathrm{x}^{2}=5.991$ at 0.05 significant levels with two degrees of freedom

As indicated in Table 6 item 1 the majority, $98(53.8 \%)$ of the teachers and $33(61.1 \%)$ of the supervisors respondents were replayed that Supervisors are not well trained in instructional supervision to give support to teachers and the activity was not practiced. On the same table of item 2 above, $112(61.5 \%)$ teachers and $36(66.7 \%)$ supervisors totally $148(62.7 \%)$ respondents revealed the non existence of workshops, seminars and short term trainings for supervisors to upgrade their skill.

On the same table of, item 3, $91(50.0 \%)$ teachers and $34(63.0 \%)$ supervisor respondents reported that experience sharing session has not been organized for instructional supervisors. The computed chi-square values $\chi^{2}=1.331$ and $x^{2}=2.327$ and $\chi^{2}=5.938$ for items 1,2 and 3 respectively were found to be less than the table value $\chi^{2}=5.991$ with two degrees of freedom at the 0.05 level of significant. This implies that there is no statistically different on the response of the two groups of respondents.

Furthermore, the response of the interview held with school principals, and secondary school supervisors also revealed that there was no any attempt made to train the instructional supervisors in the secondary school. Principals and secondary school supervisors also made little attempt to support instructional supervisors. Emphasizing the issue, one of school principal said that:

In 2007, after the region prepared training manuals as a guide and helping implementation of instructional supervision in school, training was given for experts, supervisors, and head of education office from woreda and zone as well as principals of secondary schools at regional level. But the training did not reach school level supervisors. Simply one day orientation about instructional supervision carried out for CRC supervisors, vice directors and education officials at woreda level and the same thing is done at this time. 
Availability of educational resource

Table 7. Educational resource related factors that hinder inbuilt supervision

\begin{tabular}{|c|c|c|c|c|c|c|c|c|c|c|c|}
\hline \multirow[t]{3}{*}{ No } & \multirow[t]{3}{*}{ Items } & \multirow[t]{3}{*}{ Respondents } & \multicolumn{8}{|c|}{ Responses } & \multirow{3}{*}{$\begin{array}{l}\text { Computed } \\
\chi^{2}\end{array}$} \\
\hline & & & \multicolumn{2}{|c|}{ Disagree } & \multicolumn{2}{|c|}{ Undecided } & \multicolumn{2}{|c|}{ Agree } & \multicolumn{2}{|c|}{ Total } & \\
\hline & & & No & $\%$ & No & $\%$ & No & $\%$ & No & $\%$ & \\
\hline \multirow[t]{3}{*}{1} & Adequate budget & Teacher & 95 & 52.2 & 26 & 14.3 & 61 & 33.5 & 182 & 100 & 0.457 \\
\hline & was allocated for & Supervisor & 31 & 57.4 & 7 & 13.0 & 16 & 29.6 & 54 & 100 & \\
\hline & $\begin{array}{l}\text { supervision } \\
\text { program. }\end{array}$ & Total & 126 & 53.4 & 33 & 14.0 & 77 & 32.6 & 236 & 100 & \\
\hline \multirow[t]{3}{*}{2} & Instructional & Teacher & 70 & 38.5 & 23 & 12.6 & 89 & 48.9 & 182 & 100 & 1.186 \\
\hline & $\begin{array}{l}\text { supervisors had a } \\
\text { big work load }\end{array}$ & Supervisor & 23 & 42.6 & 4 & 7.4 & 27 & 50.0 & 54 & 100 & \\
\hline & $\begin{array}{l}\text { which diminishes } \\
\text { their ability to } \\
\text { supervise. }\end{array}$ & Total & 93 & 39.4 & 27 & 11.4 & 116 & 49.2 & 236 & 100 & \\
\hline \multirow[t]{3}{*}{3} & Lack of support for & Teacher & 68 & 37.4 & 21 & 11.5 & 93 & 51.1 & 182 & 100 & 0.252 \\
\hline & $\begin{array}{lr}\text { school } & \text { based } \\
\text { supervisors } & \text { like }\end{array}$ & Supervisor & 20 & 37.0 & 5 & 9.3 & 29 & 53.7 & 54 & 100 & \\
\hline & $\begin{array}{l}\text { some guidelines and } \\
\text { checklists to } \\
\text { conduct } \\
\text { supervision. }\end{array}$ & Total & 88 & 37.3 & 26 & 11.0 & 122 & 51.7 & 236 & 100 & \\
\hline \multirow[t]{3}{*}{4} & Unavailability of & Teacher & 56 & 30.8 & 25 & 13.7 & 101 & 55.5 & 182 & 100 & 0.761 \\
\hline & $\begin{array}{l}\text { skilled and } \\
\text { experienced }\end{array}$ & Supervisor & 16 & 29.6 & 10 & 18.5 & 28 & 51.9 & 54 & 100 & \\
\hline & supervisory & Total & 72 & 30.5 & 35 & 14.8 & 129 & 54.7 & 236 & 100 & \\
\hline
\end{tabular}

The table value $\chi^{2}=5.991$ at 0.05 significant levels with two degrees of freedom

In table 7 item1, respondents were asked whether or not adequate budget was allocated for supervision program. Accordingly, the majority $95(52.2 \%)$ teachers and $31(57.4 \%)$ supervisors respondents disagreed that adequate budget was allocated for supervision program in the schools. Hence, it is possible to conclude that adequate budget was not allowed for supervision programs in the sample secondary schools of Bale zone.

As shown under table 7, the majority of teachers and supervisor respondents, that is $116(49.2 \%)$ and 122 $(51.7 \%)$ for item 2 and 3 respectively rated their agreement that have a big work load and lack of support like guidelines and check list hinder the proper implementation of instructional supervision in the secondary schools of Bale Zone. Conversely, the rest respondents, that 93 (39.4\%) and 88 (37.3\%) of teachers and supervisors for items 2 and 3 respectively expressed their disagreement to the issue.

A chi-square test was also computed to see whether there was difference among the responses of the two groups of respondents. Hence, the table value of $x^{2}=5.991$ was greater than the computed chi-square values for item 1 to 3 at significance level of 0.05 with two degree of freedom, which implies no significant difference among the two group of respondents.

Similarly, almost all of the informants who participated in the interview express that having big work load is the major problem of school based supervision. One of secondary school principal and other interview participant in one or another way said that:

Since most of our instructional supervisors were having a teaching load more than 20 periods a week, it is impossible to provide instructional supervision service to teachers. Besides, due to big workload of teachers the school forced to assign very small number of supervisors that are not adequate to provide supervisory service to all teachers.

Therefore, based on the response of majority, it is possible to conclude that having big workload and lack of budget diminishes the instructional supervisors' capacity of supervision.

Table 7 item 4 depicts, 101 (55.5\%) teachers and 28 (51.9\%) supervisors totally 129 (54.7\%) respondents agreed that in availability of experienced supervisory personnel hinder the proper implementation of instructional supervision in the schools under the study. With regard to item 4 of the same table, the computed chi-square value $\chi^{2}=0.761$ is far below the table value $\chi^{2}=5.991$ at significant level of 0.05 with two degrees of freedom. This shows us that there is no significant difference between respondents response of two groups.

Thus, based on the response of majority, it is safe to conclude that there is unavailability of experienced supervisory personnel that negatively affect instructional supervision. In relation to this assumption, as indicated 
in the literature, MOE (1994) explains that the problem of supervision in relation to our context: the shortage of time, insufficient fund and lack of qualified personnel who are facilitating the teaching learning process. Furthermore, the big workload of the supervising teachers was the major burden to carry out their supervisory role in the schools. Therefore, in order to do effective job, this problem should be overcome as a first priority.

Communication between supervisors and teachers

Table 8. Respondents views on communication skills of supervisors

\begin{tabular}{|c|c|c|c|c|c|c|c|c|c|c|c|}
\hline \multirow[t]{3}{*}{ № } & \multirow[t]{3}{*}{ Items } & \multirow[t]{3}{*}{ Respondents } & \multicolumn{8}{|c|}{ Responses } & \multirow{3}{*}{$\begin{array}{l}\text { Computed } \\
\chi^{2}\end{array}$} \\
\hline & & & \multicolumn{2}{|c|}{ Disagree } & \multicolumn{2}{|c|}{ Undecided } & \multicolumn{2}{|c|}{ Agree } & \multicolumn{2}{|c|}{ Total } & \\
\hline & & & № & $\%$ & No & $\%$ & № & $\%$ & № & $\%$ & \\
\hline \multirow[t]{3}{*}{1} & Supervisors create & Teacher & 100 & 54.9 & 19 & 10.4 & 63 & 34.6 & 182 & 100 & 9.049 \\
\hline & $\begin{array}{lr}\text { smooth } & \text { relation } \\
\text { among } & \text { teachers }\end{array}$ & Supervisor & 19 & 35.2 & 4 & 7.4 & 31 & 57.4 & 54 & 100 & \\
\hline & $\begin{array}{l}\text { themselves for the } \\
\text { improvement of } \\
\text { instruction. }\end{array}$ & Total & 119 & 50.4 & 23 & 9.7 & 94 & 39.8 & 236 & 100 & \\
\hline \multirow[t]{3}{*}{2} & Supervisors assist & Teacher & 108 & 59.3 & 12 & 6.6 & 62 & 34.1 & 182 & 100 & 4.854 \\
\hline & $\begin{array}{l}\text { teachers to feel free } \\
\text { to express }\end{array}$ & Supervisor & 25 & 46.3 & 8 & 14.8 & 21 & 38.9 & 54 & 100 & \\
\hline & $\begin{array}{l}\text { problems of } \\
\text { concern to them. }\end{array}$ & Total & 133 & 56.4 & 20 & 8.5 & 83 & 35.2 & 236 & 100 & \\
\hline \multirow[t]{3}{*}{3} & $\begin{array}{lr}\text { Teachers } & \text { develop } \\
\text { anxiety } & \text { and }\end{array}$ & Teacher & 103 & 56.6 & 14 & 7.7 & 65 & 35.7 & 182 & 100 & 1.755 \\
\hline & $\begin{array}{lr}\text { frustration } & \text { which } \\
\text { stem } & \text { from }\end{array}$ & Supervisor & 36 & 66.7 & 3 & 5.6 & 15 & 27.8 & 54 & 100 & \\
\hline & $\begin{array}{l}\text { inadequate } \\
\text { communication } \\
\text { skill of supervisors. }\end{array}$ & Total & 139 & 58.9 & 17 & 7.2 & 80 & 33.9 & 236 & 100 & \\
\hline
\end{tabular}

The table value $\chi^{2}=5.991$ at 0.05 significant levels with two degrees of freedom

As indicated in Table 8 (item 1), majority 100 (54.9\%) the teachers respondents did not agree on supervisors effort to create smooth relation among teachers and between themselves. On the other hand, the majority of supervisor $31(57.4 \%)$ respondents agreed on the stated practice. Therefore, one can infer from the above response that supervisors perceived themselves as they did best on the stated activities, even though teachers disproved it.

The computed chi-square value for item $1, \chi^{2}=9.049$ is greater than the table value of $\chi^{2}=5.991$ at 0.05 significant levels with two degrees of freedom. This implies that there is statistical significant difference between the opinion of supervisors and teacher respondents. Thus, it can be observed that teaches and supervisors have been rated differently. It can be seen that supervisors rated themselves with some better view about their skill of communication.

In connection to this, Pajak (1989) pointed out that a good supervisor is one which is capable of communicating with his subordinate in order to provide necessary guidelines and assistance to them for professional improvement. Hence, supervisors have to in a position to create smooth communication with teachers by organizing intensive in staff training in supporting and helping teachers.

Teacher and supervisor respondents were asked to give their view whether supervisors assist teachers to feel free to express problem of concern to them. Regarding this, the majority 108(59.3\%) teachers and $25(46.3 \%)$ supervisors totally $133(56.4 \%)$ respondents disagreed that on the practice. The computed chi-square $\chi^{2}=4.854$ is less than the table value $\chi^{2}=5.991$ at 0.05 significant levels with two degree of freedom. This depicts that there is no significant difference between the respondents response.

Regarding teachers developed anxiety and frustration which stems from inadequate communication skill of supervisors, the majority, $103(56.6 \%)$ teachers, and $36(66.7 \%)$ supervisors totally $139(58.9 \%)$ respondents reported their disagreement on the practice stated above. The computed chi-square value for item $3\left(\chi^{2}=1.755\right)$ is less than the table value $\chi^{2}=5.991$ at significant level of 0.05 with two degree of freedom. This indicates that there is no statistically significant difference between the views of teachers and supervisors. Hence we can understand that teachers did not develop anxiety and frustration which steam from inadequate communication skill of supervisors. 
Attempts made by instructional supervisors to solve the problems

Table 9. Attempts made by instructional supervisors

\begin{tabular}{|c|c|c|c|c|c|c|c|c|}
\hline \multirow{3}{*}{ Items } & \multirow[t]{3}{*}{ Respondents } & \multicolumn{6}{|c|}{ Responses } & \multirow{3}{*}{$\begin{array}{l}\text { Computed } \\
\chi^{2}\end{array}$} \\
\hline & & \multicolumn{2}{|c|}{ Yes } & \multicolumn{2}{|c|}{ No } & \multicolumn{2}{|c|}{ Total } & \\
\hline & & No & $\%$ & No & $\%$ & No & $\%$ & \\
\hline Are there any attempt made by & Teacher & 44 & 24.2 & 138 & 75.8 & 182 & 100 & 1.803 \\
\hline instructional supervision to & Supervisor & 18 & 33.3 & 36 & 66.7 & 54 & 100 & \\
\hline alleviate the above mentioned & Total & 62 & 26.3 & 174 & 73.7 & 236 & 100 & \\
\hline
\end{tabular}

problems

The table value $\chi^{2}=3.842$ at 0.05 significant levels with one degree of freedom

As indicated in table 9 above, the respondents were asked to mention if any attempts were made to alleviate the problems that hinder the proper practice of instructional supervision in secondary schools. Accordingly, the majority of teachers $138(75.8 \%)$ and supervisors $36(66.7 \%)$ respondents were answered that instructional supervisors did not make attempt to solve these problems. Whereas $44(24.2 \%)$ teachers and 18(33.3\%) supervisor respondents suggested attempts were made to improve or alleviate the factors that impede the proper implementation of instructional supervision in secondary schools of the study area.

Among attempts sometimes made mentioned by respondents in the open ended questions were: the continuous professional development program for newly employed teachers and school supervisors encourages experienced teachers to make collegial supervision, and to arrange various in staff experience sharing programs in department level. The result of computed chi-square value $\chi^{2}=1.803$ at 0.5 significant levels is below the table value $\chi^{2}=3.842$. This shows that there was no significant difference among the response of two groups of respondents concerning the attempt made to alleviate the problems mentioned above.

This showed that the mentoring service provided to newly employed teachers and the collegial supervision practiced among experienced teachers in department was good attempts proving school instructional supervisory service. But, in secondary schools of the study area the attempts made to alleviate the problems were low.

\section{Conclusions}

Based on the above major findings of the study, the following conclusions were made.

The practice of instructional supervision approaches in promoting teachers' professional development in making teachers; to work collaboratively, identifying their problems and work for the solution, and make mutual agreement on the lesson with supervisor is insufficient. Instructional supervision approaches enhances teachers professional development when it is practiced properly. However, the finding of the study indicated that instructional supervision would have been failed to contribute a lot in bringing professional growth, improving the teaching and learning process and student growth. Clinical supervision practice require classroom visitation in order to enhance teacher performance and to improve classroom instruction. Hence, Supervisors are expected to conduct continuous classroom observation to see how students are actually learning. However, the findings of the study noted that the clinical supervision were not capable enough to utilize the three procedures of classroom observation. Moreover, the findings showed that pre-class observation and post observation conference were held rarely in a department level. As a result, the practice failed to enhance teachers' professional development.

As the data from the interview and questionnaire indicated clinical supervision approach preferable for teachers' professional development. There for we can concluded that clinical supervision approach is the better way of teachers' professional development in addition to other approaches if it is practiced properly.

Although, Oromia Regional Education Bureau and MOE had tried to introduce instructional supervision with different strategies like induction, mentoring, peer coaching and promoting in-service training in Schools and providing supervisory service to teachers. However, the finding of the study showed that instructional supervisors were rarely practiced these strategies to promote teachers professional development. Thus, this can help to concluded that most of instructional supervisors were not aware of the responsibility they had for professional development of teaches, and failed to play their role in creating conducive environment to bring professional competence of teachers.

As shown in the findings, instructional supervision practice of instructional supervisors in sample secondary schools were ineffective in improving instructional practices of teachers, solving instructional problems, and in facilitating teacher-parent partnership. Besides it was found that the instructional supervision practice was not effective in facilitating teacher work, in preparation and provision of teaching manuals and materials, in evaluating the existing curriculum, in implementing curriculum and adapting the curriculum to the school context. Therefore, it is possible to conclude that instructional supervision was not adequately practiced in secondary schools of Bale zone.

As the result of the study revealed, the instructional supervision practice was hindered by the availability of some teachers perceived supervisory service negatively, lack of in-service training and experience sharing session 
for school supervisors, failure to organize in-service training for teachers, lack of supports, insufficient budget, unavailability of experienced supervisory personnel, big teaching (work) load of school supervisors and inadequate communication skills of school based supervisors. As a result, instructional supervision service and professional support provided to teachers in secondary school of Bale zone was not adequate.

\section{Recommendations}

Based on the findings, the study forwarded the following recommendations

It is advisable for regional education bureau, zonal education office, Woreda education office and different stakeholders to work collaboratively for the effectiveness of the practices of different instructional supervision approaches for teachers' professional development. By giving training, experience sharing and other capacity building programs for instructional supervisors for the effectiveness of the practice. Instructional supervisors and teachers should motivated and trained in conducting different supervisory approaches by assessing their teaching, doing action research on the problem they faced and to work collaboratively to solve their problem.

Besides, instructional supervisors are required to give emphasis to the creation of awareness in teachers; have to reach an agreement with teachers on purpose and procedures of classroom observation, and have to conduct all classroom observation procedures in a planed manner.

To make teaches professionally competent, different strategies of instructional supervision like induction or monitoring, collegial supervision and in-service trainings are recommended to be carried out in the schools. School and Woreda education offices should made strong effort to improve the practices of in-service trainings, induction or monitoring and collegial supervision to facilitate teachers' professional development.

The Oromia Region Education Bureau should give opportunities of assessing achievements and failures of supervisory practice. Common consensus should be facilitated by school officials, Woreda and zone education officials. All concerned bodies (the OREB, ZEB, WEB and school officials in collaboration with NGOs) are recommended to take Short-term refreshment trainings through seminars, workshops or through discussion forums should be organized and implemented for instructional supervisors and teachers. Trainings should be plan and implemented effectively so as to help the participants to develop their skill and knowledge of instructional supervision.

Experience sharing programs regarding instructional supervision within school and across secondary schools in the zone should be design and implemented by joint efforts of schools, zone and woreda education offices. Adequate budget needs to be allocated for instructional supervisors so as to improve the supervisory service at school. In order to provide adequate supervisory support to teachers the number of instructional supervisors in school should be assigned as stated in the guideline of instructional supervision manual of the region.

\section{Acknowledgments}

Researchers would like to thank Bale zone Secondary school principals' supervisors, teachers and who actively participated in the study in sharing their experiences and outlooks on the Practices of Instructional Supervision in Secondary Schools of Bale Zone of Oromia Region on the study area.

Conflict of Interest

The researchers would like to declare there is no conflict of interest in this research authorship. In case, if anyone claims co-authorship the current researchers would take the full responsibility for any measure.

\section{References}

Aggarwal, J. 1985. Theory and Principles of Education: Philosophical and Sociological Bases of Education. New Delhi: Vikas Publishing House Pvt. Ltd.

Ahmed, M. 1998. Trends in School Supervision for Teacher Development: a Proposal for Pakistan. Paris: UNESCO. Retrieved on November 28/2012 from http://unesdoc.unesco.org/images.pdf

Atiklt Desta. 2008. The Status of School in Built Instructional Supervision in Government Secondary Schools of Mekele Zone. Addis Ababa University (Unpublished MA thesis).

Barr, A.S, WB Burton and Leo J. Brueckner. 1974. Supervision: Democratic Leadership (Second edition). New York: Appletion Century Craft, Inc.

Beach, D. M., and Reinhartz J. 2000. Supervisory leadership: Focus on instruction. Boston: Allyn and Bacon.

Best, John. W. and James Khan. 2003. Research in Education $7^{\text {th }}$ edition. New Delhi: Prentice-Hall of India.

Carron, G.A. De Grauwe and R. Govinda. 1998. Supervision and Support Service in Asia. A comparative analysis. Paris NUESCO/NESCO/International Institute for Educational Planning.

Chanyalew Wold Gegebriel. 2005. The Practice and Problems of Instructional Supervision in Secondary Schools of Hadya Zone. Addis Ababa University (Unpublished MA Thesis).

Cohen, D. K. and H.C. Hill. 2001. Learning policy. New Haven, CT:Yale University Press.

Cohen, L., Lawrence M. and M. Keith. 2005. Research Methods in Education $5^{\text {th }}$ edition. London: Taylor and Francis e Library. 
Darling-Hammond, L. and M.W. McLaughlin. 1996. Policies that support the professional development in an era of reform. Phi Delta Kappan. 76(8): 597-604.

Drake, T.L., and Roe, W.H. 1999. The Principal ship $5^{\text {th }}$ edition. Columbus, Ohio: Prentice-Hall.

Dull, L.Loyd, W. 1981. Supervision: School Leadership Handbook. Ohio Charles E.Merril Pub.C.

Ebmeier, H., and Nicklaus, J. 1999. The impact of peer and principal collaborative supervision on teachers' trust, commitment, desire for collaboration, and efficacy. Journal of Curriculum and Supervision, 14(4):351-378.

Elmore, R. F. 2002. Bridging the gap between standards and achievement: the imperative for professional development in education. Paper for Albert Shanker Institute.

Garet M., Potter, A. Desimonel., Birman B., and K.S. Yoom 2001. What makes professional development effective? Results from a national sample of teachers. American Educational Research Journal. Vol. 38(4): 915-945.

Glatthorn, A. A. 1990. Supervisory leadership: Introduction to instructional supervision. New York: Harper Collins.

Glickman, C. D., Gordon, S. P. and Ross-Gordon, J. M. 1998. Supervision of instruction: A developmental approach 4th edition. Boston: Allyn and Bacon.

Glickman, Carl, D. Gordon, Stephen, D. and Ross, Gordon, Jovlta, M. 2004. Supervision and International Leadership; Development Approach. USA: Pearson Education Inc.

Goldhammer, R. Anderson, R. and Karjewski, R. 1980. Clinical Supervision: Special Methods for the Supervision of Teachers. New York: Rinehart, and Winston.

Goldhammer, R., Anderson, R. H., and Krajewski, R. J. 1993. Clinical Supervision: Special Methods for the Supervision of Teachers $3^{\text {rd }}$ edition. Toronto, ON: Harcourt Brace Jovanovich College Publishers

Guskey, T.R. 2000. Professional development and teachers change. Journals of Teachers and Teaching: Theory and Practice. 8(3): 381-391.

Haile Abbay. 2006. Practices and Problem of School-Based Supervision in Selected Secondary Schools of Central Zone of Tigray. AAU (Unpublished MA Thesis)

Haileselassie W/gerima. 1997. Educational Supervision Teaching Material. Addis Ababa University, Faculty of Education.

Haileselassie W/gerima. 2007. Educational Supervision. Department of Educational Planning and Management, College of Education, Addis Ababa University.

Hailesilasse Fisshea. 2004. The Status of Professional Development Program in Addis Ababa City Administration. Addis Ababa University (Unpublished MA Thesis).

Harison, Raymond, H. 1968. Supervisory Leadership in Education. New York: Van Nastrend Rein Hold Co.

Harris, B.M. 1985. Supervision Behavior in Education. London: Prentice Hall international, Inc.

Hopkins, D. Beresford, J. and West, M. 1998. Creating Condition for Classroom and Teacher Development, Teacher and Teaching. Vol. 4, 1, pp. 115-141.

Hosack-Curlin, K. 1993. Peer coaching among teachers. In R. H. Anderson and K. J. Snyder (Eds.), Clinical supervision: Coaching for higher performance (pp. 231- 250). Lancaster, PA: Technomic.

Hoy, W. K. and Forsyth, P. D. 1986. Effective supervision: Theory into practice. New York: Random House.

Jhonson, D.W. and Jonson, F.P. 2000. Joining Together: Group Theory and Group Skills $7^{\text {th }}$ edition. Englewood Cliffs, NJ: Prentice Hall

Jonasson, H. 1993. Effective schools link professional development, teacher supervision, and student learning. The Canadian School Executive, 13(2):18-21.

King, M.B. and F.M. Newman. 2000. key Link: successful professional development must consider school capacity. Journal of Stuff Development 25(1): 26-30.

Leeper, Robert Rosborogh.1969. Supervision Emerging Profession and Current Development. Washington NEA. Lingard B., Hayes D., Mills M. and P.Christie. 2003. Leading Learning. Maidenhead, UK: Open University press.

Little, J. W. 1993. Teachers' professional development in a climate of educational reform. Educational Evaluation and Policy Analysis, 15(2): 129-151.

Lucio, William, H., and John, D. McNeil. 1979. Supervision: A Synthesis of Thought and Action $3^{\text {rd }}$ edition. New York:McGraw-Hill.

Lue, E. 2004. School and Cluster-Based Teacher Professional Development: Bringing Teacher learning to the School-Retrieved on September 10, 2012 from http://www.equip123-net/docs/EQ1 working paper/pdf.

McBridge. 1996. Teachers Education Policy: Some Issues Arising from Research and Practice: London Falmer Press.

McQuarrie, F. O., Jr., and Wood, F. H. 1991. Supervision, staff development, and evaluation connections. Theory into Practice, 30(2):91-96.

MoE. 1994. Supervision Manual. Addis Ababa.

MoE. 1994. The education and Training Policy of the Federal Republic of Ethiopia: Addis Ababa, Ministry of Education.

MoE. 1995. Supervision Manual. Addis Ababa. Minster of Education. 
MoE. 2002. Education Sector Development Program II. Addis Ababa.

MoE. 2004. Continued Professional Development: Guide Line for School Teachers. Addis Ababa.

Mohanty, B. 1990. School Administration and Supervision. New Delhi: Deep and Deep Publications.

Montee, Sullieean. 1990. Applied Social Research Tools for the Human Services. London, UK: Printer Publishers. Sudman.

Montgomery, D. and Hadield. 1992. Practical Teacher Appraisal. London: Kogan Page Ltd.

Moon, John Bukan and Elzabet. 2001. Leadership Development in Education: Open University. London

OREB. 2007. Maanwallil Adeemasa Hoji Kenna Degarsa Ogummaa fi Hordoffii Barnootaa. Garee JBAH BBO: Finfinee.

Pajak, Edward. 1989. The Central Office Supervisor of Curriculum and Instruction: Setting the Stage for Success. Boston: Allyn and Bacon, Inc.

Pfeiffer, I. L., and Dunlap, J. B. 1982. Supervision of Teachers: A guide to improving instruction. Phoenix, AZ: Oryx Press.

Reiman, A. J. and Thies-Sprinthall, L. 1998. Mentoring and Supervision for teacher development. New York: Longman.

Robert V. Krejcie 1970, Educational And Psychological Measurement: Determining Sample Size For Research Activities. University Of Minnesota, Duluth Daryle W. Morgan Texas A. \& M. University

Sergiovanni, J. 1995. The Principal Ship. A Simon and Schuster Company, Needham Heights.

Sergiovanni, J. and Starratt, R. J. 1998. Supervision: A Redefinition $6^{\text {th }}$ edition. New York: McGraw-Hill.

Sergiovanni, J. and Starratt, R. J. 2002. Supervision a Redefinition. New York: McGraw-Hill Companies.

Shukla, P.D. 1983. Administration of Education in India. NewDelhi: Vikas Publishing House Pvt-Ltd.

Singhal. 1996. School Inspection System: Modern Approach. New Delhi: Vikas Publishing House Pvt Ltd.

Sirotnik, Kenneth, A. and Oakes, J. 1996. Critical Perspective on the Organization and Improvement of Schooling. Boston: Kluwer Nijh of Publishing.

Spears Harold. 1995. Improving the Supervision of Instruction. New York: Prentice Hall Inc.

Starling, P. V., and Baker, S. B. 2000. Structured peer group practicum Supervision: Supervisees' perceptions of supervision theory. Counselor Education and Supervision, 39(3):162-176.

Sullivan, C. G. 1997. Is staff development supervision? Yes. In J. Glanz \& R. F. Neville (Eds.), Educational supervision: Perspectives, issues, and controversies (pp. 156-161). Norwood, MA: Christopher-Gordon.

Tanner, D. and Tanner, L. 1987. Supervision in Education: Problems and practices. New York: Macmillan.

UNESCO. 2001. Trends in School Supervision in Four African Countries: National Diagnosis. Vol. 2. Educational Planning.

Villegas-Reimers, E. 2003. Teachers professional development: An international review of the literature. UNECO: International Institute for Educational Planning, Paris. 197p.

Wanzare, Z., and Da Costa, J. L. 2000. Supervision and staff development: Overview of the literature. NASSP Bulletin, 84(618): 47-54.

West, M. and R. Bollington. 1990. Teachers Appraisal: A Practical Guide for Schools. London David Fulton Publishers.

Willington, J.J. 1996. Methods and Issues in Education Research. London: Impact Graphics.

Wood, F. H., and Thompson, S. R. 1993. Assumptions about staff development based on research and best practice. Journal of Staff Development, 14(4): 52-57. 